\title{
Development of the Edge of the Gully in the Zone Adjacent to the Field
}

\author{
Roman Rybicki ${ }^{*}$, Radomir Obroślak', Andrzej Mazur', Antoni Grzywna', Artur Serafin ${ }^{1}$ \\ 1 Department of Environmental Engineering and Geodesy, University of Life Sciences in Lublin, ul. \\ Leszczyńskiego 7, 20-069 Lublin, Poland \\ * Corresponding author's e-mail: roman.rybicki@up.lublin.pl
}

\begin{abstract}
The development of the side arm edge of the valley-gully in Gałkowice village in the Dwikozy commune (the Opatówka catchment in the Sandomierz Upland) was investigated during the period from 2002 to 2017. An increase of fragmentation of the gully edge was found. Most of the pre-existing erosive indents increased in size (maximum of $2.8 \mathrm{~m}$ - about $0.2 \mathrm{~m}$ per year). An increase in the area of the gully by $145 \mathrm{~m}^{2}$ was found. As a result, the boundary of plow tillage shifted to an average of 1.5 to 2 meters (maximum $3.8 \mathrm{~m}$ ), which resulted in a loss of $545 \mathrm{~m}^{2}$ of adjacent arable land. As the main reason for the development of the analyzed section of the gully, meltwater flows were considered.
\end{abstract}

Keywords: gully erosion, gully development, Sandomierz Upland

\section{INTRODUCTION}

Gully erosion is one of the most dangerous forms of water erosion [Casalí et al. 2006], largely shaping the sculpture of loess upland areas [Józefaciuk and Józefaciuk 1992; Valentin et al. 2005]. This type of erosion is recognized as a large source of soil loss and a substantial contributor to the sedimentation of rivers, small ponds and large reservoirs [Fox et al. 2016]. As a rule, gullies form as a result of a systematic process of washing out soil particles on lines of periodic, concentrated water runoff lasting for hundreds of years [Maruszczak 1988; Zegeye et al. 2018; Zgłobicki et al. 2014]. Large forms of gully may also develop rapidly, during a single catastrophic rain or thaw runoff [Buraczyński and Wojtanowicz 1974; Cerdan et al. 2002; Onyelowe et al. 2018; Rodzik 2008]. The occurrence of gullies is most often found in longitudinal depressions on agricultural slopes and ground roads [Kirkby 2007].

In addition to many natural factors conditioning the development of gully erosion (rainfall, geology, hydro- and physiography of the terrain) [Daggupati et al. 2014; Zhang et al. 2007], an- thropogenic factors have serious or sometimes crucial importance. Among them, the most important is the structure of land use [Dotterweich 2008; Oparaku et al. 2018; Valentin et al. 2005; Zhao et al. 2013].

According to Józefaciuk and Józefaciuk [1992], gully erosion occurs on about $18 \%$ of Poland's area, and the total length of gullies is about $50000 \mathrm{~km}$. Out of that about $50 \%$ are road gullies. The most developed network of gullies is characterized the Małopolska province. Ravines occur in about $53 \%$ of this area; hence, it is classified for first degree of urgency of protection. Among the loess physiographic lands, the Nidziańska Basin and Lublin Upland are the most heavily cut by ravines, whereas Roztocze is the area most fragmented by gullies in Poland. The Kielce-Sandomierz Upland, although it is covered with a deep cladding of loess, naturally very susceptible to fuzziness, is fragmentised by gullies to a medium degree. Only the areas surrounding Sandomierz are defined as an area of strong density gullies ( 1 to $2 \mathrm{~km} \cdot \mathrm{km}^{-2}$ ). The density of incises over $2 \mathrm{~km} \cdot \mathrm{km}^{-2}$ occurs on the sections of the slopes of the Vistula valley between Sandomierz and Zawichost. 
The fertility of loess soils and favourable agro-climatic conditions mean that these areas have been farmed from time immemorial. An example of this is the Sandomierz Upland - part of the Kielece-Sandomierz Upland lying between the Świętokrzyskie Mountains and the Vistula. According to Dylikowa [1973], the last larger forest complexes were destroyed here in the late Middle Ages. Already in the fifteenth-sixteenth century, the plundering grange-serfdom economy contributed to the beginning of the rain-wash processes and even heavy dismembering of the relief. In this period, the network of loess gullies, existing to this day, was probably created [Maruszczak 1988]. The intensity of erosion processes of the Sandomierz Upland in this period is evidenced by the abundant accumulation of loess deluvium at the Holocene bottom valleys, which began in the fifteenth century [Kolodynska-Gawrysiak et al. 2018; Kosmowska-Suffczyńska 1983]. At present, the intensity of soil erosion has not been reduced. It is a result of reducing the area of crops protection of soil during winter and spring thaw, generally small area of forests and still accidental, often inappropriate allocation of them at the sculpture.

The Sandomierz Upland has a relatively poor river network. There is Opatówka, and on the southern edge - Koprzywianka. In the slopes of valleys of these rivers, gully networks were created and the extent of their catchment determines the density of the gully network throughout the entire Upland [Pałys and Węgorek 1998]. Opatów$\mathrm{ka}$ incised in the surrounding area about $50 \mathrm{~m}$ at the mouth and about $30 \mathrm{~m}$ in the middle course. The catchment is quite narrow, at its widest point it reaches $10 \mathrm{~km}$. With such a deep indentation of the bottom of the valley, the slopes are very steep and cut up by numerous gullies [Mazur 1963]. Many of these gullies have reached the last stage of development and have the character of extensive dismembered valleys. Until recently, most of their slopes were cultivated. Currently, they are a mosaic of arable fields, fallow lands, thickets and high plantings. An example is the extensive complex of gullies-valleys on the left hand slope of Opatówka in the area of Gałkowice and Kichary village, made up of the ranges: "Daleniowe Dołki”, "Żmudów Dół", "Stanowiska", "Rozdół” [Pałys and Węgorek 1998].

The aim of this work was to assess the development of a selected section of gully edge in the zone adjacent to the cultivated field and its impact on changes in the course of the border of arable land.

\section{CHARACTERISTICS OF THE FACILITY AND METHODS}

The object under examination is a fragment (side branch) of one of the gullies (Figure 1) presented in the work of Pałys and Weqgorek [1998] as a peculiarity of Sandomierz region. This gully, with a length of about 3 kilometers and an area of $28.3 \mathrm{ha}$, was formed on the bottom of the agriculturally used valley, which is a micro basin of the left bank of the mouth course of the Opatówka river. The microbasin with an area of approximately 387 ha is located in the Gałkowice village (Dwikozy commune, Sandomierz district). The mouth segment of this gully as a vast valley is at the stage of old age. The central segment of the ravine is also stabilized and without erosion. The forehead of the gully and its branches, i.e. side cuts of the first and subsequent stages, are active, cutting into adjacent agricultural lands.

According to Woś [1993], the Opatówka river basin belongs to the Central Upland District; however, due to the very low rainfall, the climate is not much different from the climate of the belt of the Great Valleys. The highest rainfall occurs in July (from $80 \mathrm{~mm}$ in dry years to $190 \mathrm{~mm}$ in wet years). The driest season is winter (XII-II), the sum of rainfall varies between $49-64 \mathrm{~mm}$. The average an-

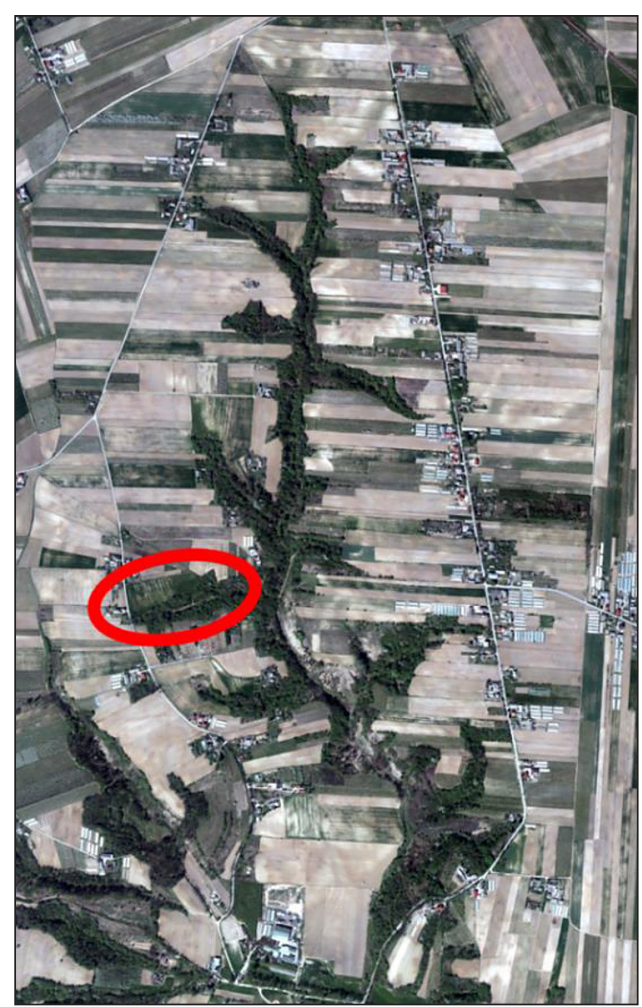

Fig. 1. Walley-gully in Gałkowice (Opatówka basin) and localization of the study area 
nual rainfall oscillates between 490-700 $\mathrm{mm}$, with a long-term average of $550 \mathrm{~mm}$. The area around Sandomierz is considered as warm. The average annual air temperature is about $8^{\circ} \mathrm{C}$, the average temperature of the warmest month (July) is about $18^{\circ} \mathrm{C}$, while the coldest (December) is $2.7^{\circ} \mathrm{C}$ [Miczyński and Siwecka 2012].

The layout of the gully-edge and the boundary of the field adjacent to the gully were examined in 2002 and the measurement was repeated in 2017. This enabled to analyse the changes that have occurred over the 15 years. In 2002, the measurements were made using the rectangular offset method. In 2017, the measurements were carried out using the GNSS-RTK method using the Topcon HiPer V controller. In order to unify the data, the results from 2002 were transformed into coordinates in the 2000 system. For this purpose, WinKalk surveying software and the coordinates of points of the previously assumed measuring network were used. The visualization of the results and measurements of the shift of the gully and field lines together with the measurement of the area of observed changes were carried out in the EWMapa program.

\section{RESULTS AND DISCUSSION}

The high erosion risk of the terrain is evidenced by its rich and dynamic sculpture - the gully covers $7.3 \%$ of the catchment area, while the slopes $59.2 \%$ (about $14 \%$ of which are those with a slope greater than 15\%) [Rybicki 2009]. Small forest cover, amounting to about $9 \%$ and the location of forests mainly within the ravine, means that the slopes are mainly taken by plow cultivation. At the same time, the longitudinal arrangement of fields often reaching the edge of the ravine, additionally increases the erosion processes. It causes shallowing and depletion of the soil and initiation of the pipping process (activing the gully) [Echeverría et al. 2007; Kirkby 2007].

On the analysed section of the edge of the gully (similarly as in the whole catchment area), the adjacent arable land is cultivated along the slope, directly reaching to the edge of the gully (Fig. 2, 3a, 3b). Although the area has a relatively small slope of about $10-12 \%$, and the gully is forested, it is observed activing various erosive phenomena, such as young indentations or suffosion kettles. This causes further development of the gully and cutting it into the cultivated fields. This is mainly due to the lack of a transition zone between the arable land and gully (biological collars), which causes that water from thaw and rain runoff runs directly to the edges of the erosive indentation. The physical properties of the soil, in particular soil permeability, are not insignificant. The filtration coefficient of top soil layers in pits I and II (Figure 2) reaches the values close to $0 \times$ $10^{-6} \mathrm{~cm} \cdot \mathrm{s}^{-1}$ [Rybicki 2006]. It does not allow the rainwater to soak into the soil. Another reason for the spread of the gully (formation of its new branches) outside the longitudinal arrangement of fields is the incompetent use of agricultural tools. In the 15-year observation period, it was noticed several times that the beginning of plow cultivation outside the field line caused that the created furrow was quickly transformed into a new ero-

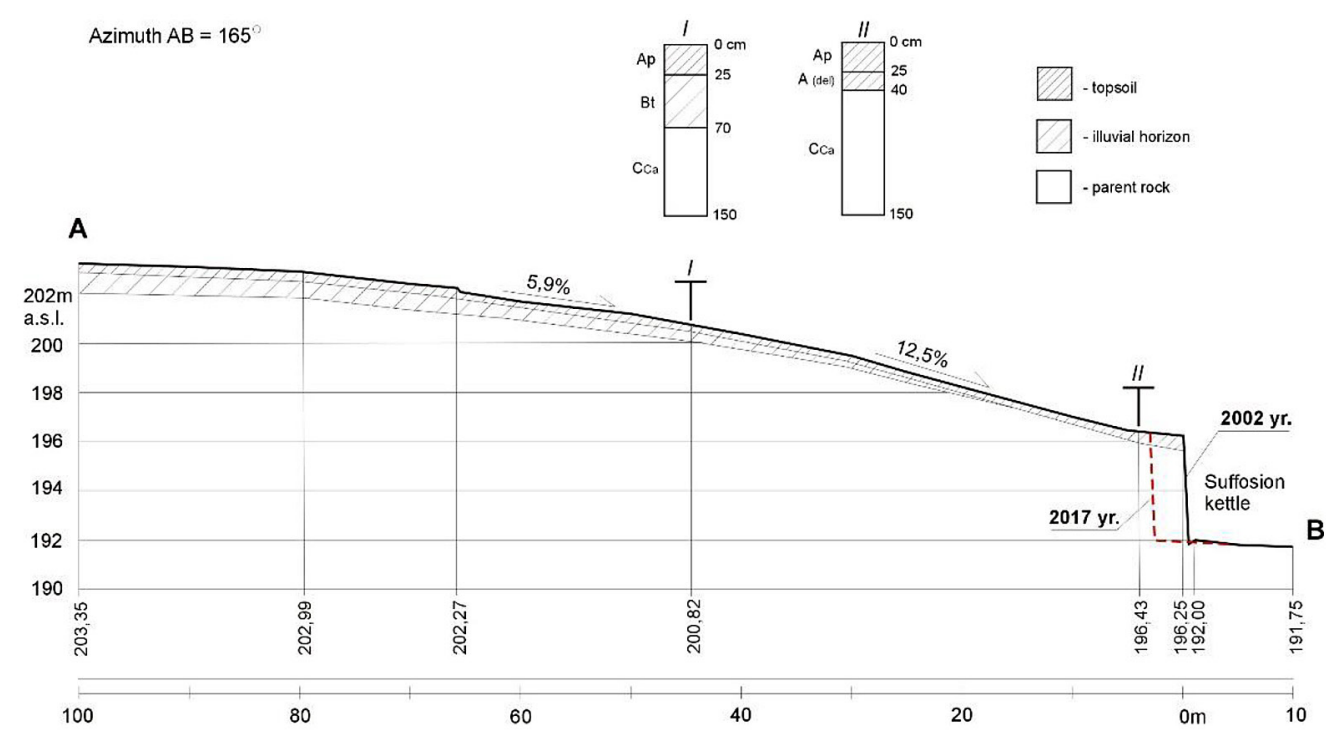

Fig. 2. A-B levelling-soil cross-section (location of the cross-section as in Figure 4) 
sive incision. The size of losses resulting from erosion is also evidenced by the amount of muds deposited in the bottom of the gully (Fig. 3c) the soil material comes from both the developing branches of the gully and eroded arable fields. As a result, the examined branch of the gully, from the initially V-shaped cross-section, changed into U-shaped, where no secondary blurring is currently observed.

The layout of the edge of the gully and the border of plow cultivation in 2002 and 2017 is illustrated in Figure 4. The length of the gully edge at the beginning of the research was approximately $475.5 \mathrm{~m}$. However, in 2017, an extension of approximately 30 meters was found. This is the result of the increase in edge fragmentation. Many erosive indents (kettles) increased their size and new ones were created. One of the suffosion kettles (shown in figures 2 and 3a) moved into the arable land by $2.8 \mathrm{~m}$. This means the average moving of about $0.2 \mathrm{~m}$ during the year. Finally, the increase in the surface of a gully by about 145 $\mathrm{m}^{2}$ was concluded. Assuming that the majority of the erosive indents have a depth of 4 to 5 meters, the total volume of the eroded material from the developing gully on the test section could amount over $700 \mathrm{~m}^{3}$. The development of the gully was not without significance to the border of the adjacent field, i.e. the border of plow cultivation. It has shifted an average from 1.5 to 2 meters, with a maximum of $3.8 \mathrm{~m}$. This resulted in a loss of arable land by $545 \mathrm{~m}^{2}$.

Apart from the anti-erosion management of land, the climatic conditions have a great influence on the development of the young gully indentations [Cerdan et al. 2002; Rodzik 2008]. In the Sandomierz Upland, the summer half-year, when the sum of rainfall is around $70 \%$ of annual [Miczyński and Siwecka 2012] and is quite high compared to other regions of Poland is the most predisposed in this respect [Czarnecki 1996]. From the agricultural point of view, this is a completely beneficial phenomenon; however, due to the low retention capacity and low soil protection of forests, resulting primarily from their small share in the total catchment area (forests are located only within the ravine and constitute $9 \%$ of the total catchment area), - the occurrence of very wet springs, years and autumn, in which the most rainfall $>10 \mathrm{~mm}$ is also recorded, potential conditions for water erosion are created. The summer half-year is also the


Fig. 3. Investigated gully: a) suffosion kettle cutting into the arable land; b) the border of plow cultivation; c) silted bottom of the gully (Photo: R. Rybicki) 


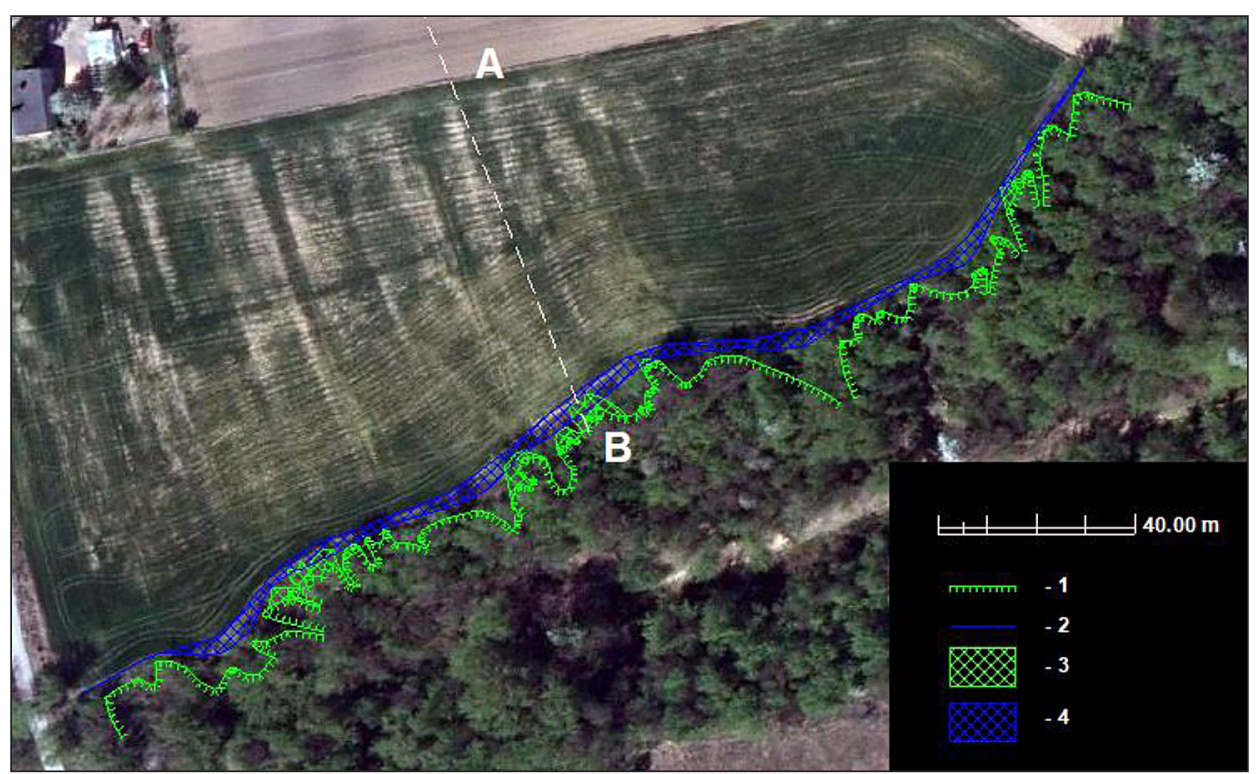

Fig. 4. Edge of the gully and cultivation border; location of the AB soil-levelling cross-section on the background of aerial photography: 1) edge of the gully in 2002; 2) cultivation border in 2002; 3) repositioning of edge of the gully in 2017 ; 4) repositioning of cultivation border in 2017

time of storms. For the Opatówka basin, their number is $25-27$, and the number of days with storms 21-23 [Czarnecki 1996].

The climatic period, equally conducive to erosion, are spring thaws the share of which in soil degradation is estimated at about $40-50 \%$ of annual losses. Here, the climate change is of great importance. There are both winters with repeated slow thaw of snow as well as frosty winters ending in sudden warming, when ideal conditions for surface runoff and back erosion (gully) are created. In addition, night frosts cause the formation of ice efflorescence in the sodden soil layer and the daily warming results in the loosening of this layer. Under favourable conditions, it causes creeping up of soil (solifluction) [Andruszkiewicz 1973].

According to Rodzik [2008], flowing snowmelt causes spatial development of gullies and their shallowing. However, rainfall deepens the gullies and takes the material out of the basin. Because in the case of the researched gully, intense, spatial development of the edge is observed, while sediments are deposited in its bottom, therefore, the meltwater flows should be considered as the main cause of development of the analyzed section of the gully.

In order to prevent further development of the investigated gully, and, for example sediment loads in rivers related to this, designing cost-effective measures to treat gullies should be a priority
[Zegeye et al. 2018; Zhao et al. 2013]. Above all, particular attention should be paid to the use of its margins. Although they are characterized by small falls, they are an important element securing the gully. In the first place, it will be necessary to introduce "biological collars" over the edges of the erosive indentations with a width equal to at least the height of slopes in a given place [Patro and Węgorek 2001, Rybicki 2006]. This will also distance the border of plow cultivation to a safe distance. Next, it will be necessary to change the direction of agricultural treatments into across slope and introduce special erosive rotations, which protect the soil during surface runoffs [Rybicki 2006]. One of the possibilities is also to change the way of using the adjacent arable land to the orchard. At the same time, it would be advisable to establish fruit plantations such as raspberries, currants or chokeberry. These crops, grown in transverse rows, can effectively disperse water flows. Therefore, the greatest hopes in this respect should be seen in the rural management works, carried out in accordance with the principles of anti-erosion melioration [Nowocień 2006].

\section{CONCLUSIONS}

1. The study confirmed that the lateral branches of the loess gullies being in the stage of old age may be still eroded and cut into adjacent agricultural lands. 
2. In the studied fragment of the side arm edge of the valley-gully in Gałkowice, in the period from 2002 to 2017, an increase of fragmentation of gully edge was found, which resulted from the development of the majority of preexisting erosive indents.

3. The development of the erosive indentations reaching $2.8 \mathrm{~m}$ was observed, which gives an average of about $0.2 \mathrm{~m}$ per year.

4. An increase in the area of the examined part of the gully by $145 \mathrm{~m}^{2}$ was found.

5. The boundary of plow tillage shifted to an average of 1.5 to 2 meters (maximum $3.8 \mathrm{~m}$ ), which resulted in a loss of $545 \mathrm{~m}^{2}$ of adjacent arable land.

6. In order to prevent further development of the investigated gully, appropriate measures of its protection should be designed and implemented. This is possible during the rural management works, carried out in accordance with the principles of anti-erosion melioration.

\section{REFERENCES}

1. Andruszkiewicz A. 1973. Genesis and development of gully forms in the central basin of Opatówka. Prace i St. IGUW, 14, Geogr. Fiz. 5, 101-121. (in Polish)

2. Buraczyński J., Wojtanowicz J. 1974. Development of loess ravines near Dzierzkowice in the Lublin Upland under the influence of a heavy downpour in June 1969. Annales UMCS, B, 26, 135-168. (in Polish)

3. Casalí, J., Loizu, J., Campo, M.A., De Santisteban, L.M., and A'lvarez-Mozos, J. 2006. Accuracy of methods for field assessment of rill and ephemeral gully erosion. Catena, 67, 128-138.

4. Cerdan O., Le Bissonnais Y., Couturier A., Bourennane H., Souchere V. 2002. Rill erosion on cultivated hillslopes during two extreme rainfall events in Normandy, France. Soil Tillage Res., 67(1), 99-108.

5. Czarnecki R. 1996. Sandomierz Upland. The eastern part. Published by the author's own effort, Warsaw. (in Polish)

6. Daggupati P., Sheshukov A.Y., Douglas-Mankin K.R. 2014. Evaluating ephemeral gullies with a process-based topographic index model. Catena, 113, 177-186.

7. Dotterweich M. 2008. The history of soil erosion and fluvial deposits in small catchments of central Europe: Deciphering the long-term interaction between humans and the environment. Geomorpgology, 101, 192-208.
8. Dylikowa A. 1973. Geography of Poland, geographical regions Wyd. Państwowe Zakłady Wydawnictw Szkolnych. Warszawa. (in Polish)

9. Echeverría M.T., Ibarra P., Pérez-Cabello F. 2007. Agricultural land use, piping and gullies activity in the Huelva lower valley (Saragossa, Spain). Casalí J. and Giménez R. (Eds.): Progress in Gully Erosion Research. Universidad Pública de Navarra, Spain. 44-45.

10. Fox G.A., Sheshukov A.Y., Cruse R., Kolar R.L., Guertault L., Gesch K.R., Dutnell R.C. 2016. Reservoir Sedimentation and Upstream Sediment Sources: Perspectives and Future Research Needs on Streambank and Gully Erosion. Environ. Manag., 57, 945-955.

11. Józefaciuk Cz., Józefaciuk A. 1992. Density of the gully network in the physiographic provinces of Poland. Pam. Puł., 101 (supl.), 5-23. (in Polish)

12. Kirkby M.J. 2007. Gully dynamics: initiation and morphology (Keynote). In. Casalí J. and Giménez R. (Eds.): Progress in Gully Erosion Research. Universidad Pública de Navarra, Spain. 64-65.

13. Kolodynska-Gawrysiak R., Poesen J., Gawrysiak L. 2018. Assessment of long-term Holocene soil erosion rates in Polish loess areas using sedimentary archives from closed depressions. Earth Surface Processes and Landforms. 43 (5), 978-1000.

14. Kosmowska-Suffczyńska D. 1983. Influence of human activity on the rate of growth of alluvial in valleys and changes in the landscape on the example of the Czyżówka valley (Sandomierz Upland). Prace i Studia Geogr. UW, 4, 69-78. (in Polish)

15. Maruszczak H. 1988. Changes of the natural environment of the country in historical times. In. Starkel L. (ed.): Transformation of the geographical environment of Poland. Wszechnica PAN, 109135. (in Polish)

16. Mazur Z. 1963. Water erosion of soils in the Opatówka river basin Wiad. IMUZ, 3, (2), 7-20. (in Polish).

17. Miczyński J. Siwecka M. 2012. Climate change in Sandomierz in 1971 - 2006. Inż. Ekol., 30, 97-118. (in Polish)

18. Nowocień E. 2006. Antierosion melioration in the process of management of rural areas. In: Woch F. (Ed.) Comprehensive consolidation of agricultural and forest land and its impact on the environment. Mat. szkol. Nr 93. IUNG-PIB Puławy, 156-159. (in Polish)

19. Onyelowe K.C., Bui Van D., Ikpemo O.C., Ubachukwu O.A., Van Nguyen, M. 2018. Assessment of rainstorm induced sediment deposition, gully development at Ikot Ekpene, Nigeria and the devastating effect on the environment. Environmental Technology and Innovation, 10, 194-207. 
20. Oparaku L.A., Oluwaseun D.A., Ogbeh G.O. 2018. Anthropogenic factors influencing the development of gullies on the Idah-Ankpa Plateau of north central Nigeria. Journal of Soil and Water Conservation, 73 (4), 90A-95A

21. Pałys S., Węgorek T. 1998. Loess gulies as a peculiarity of Sandomierz region. In: Puszkar T. (Ed.) Peculiarities of the nature of the Sandomierz Land. Wyd. Diecezjalne w Sandomierzu, 21-29. (in Polish)

22. Patro M., Węgorek T. 2001. Ways of managing of gullies in the conditions of structural changes in agriculture. Inżynieria Ekologiczna, 5, 109-116. (in Polish).

23. Rodzik J. 2008. The impact of heavy rain and thaw on the development of the loess gully. Landform Analysis, 8, 56-59. (in Polish)

24. Rodzik J., Furtak T., Zgłobicki W. 2009. The impact of snowmelt and heavy rainfall runoff on erosion rates in a gully system, Lublin Upland, Poland. Earth Surf. Proces. Landforms, 34, 1938-1950.

25. Rybicki R. 2006. Development of land threatened by erosion in the light of sustainable agriculture. Inżynieria Rolnicza. 6 (81), 231-237. (in Polish)

26. Rybicki R. 2009. Change of use of eroded loess soils on example of the Opatówka catchment microbasin. Zesz. Probl. Post. Nauk Roln. 535, 365-
371. (in Polish)

27. Valentin C., Poesen J., Li Y. 2005. Gully erosion: Impacts, factors and control. Catena, 63 (2), 132-153.

28. Woś A. 1993. Climate regions of Poland in the light of the frequency of different types of weather. Zesz. Instytutu Geografii i Przestrzennego Zagospodarowania PAN Warszawa. (in Polish)

29. Zegeye A.D., Langendoen E.J., Guzman C.D., Dagnew D.C, Amare S.D, Tilahun S.A., Steenhuis T.S. 2018. Gullies, a critical link in landscape soil loss: A case study in the subhumid highlands of Ethiopia. Land Degradation and Development, 29 (4), 1222-1232.

30. Zhang, Y.; Wu, Y.; Liu, B.; Zheng, Q.; Yin, J. 2007. Characteristics and factors controlling the development of ephemeral gullies in cultivated catchments of black soil region, Northeast China. Soil Tillage Res., 96, 28-41.

31. Zhao G., Mu X., Wen Z., Wang F., Gao P. 2013. Soil erosion, conservation, and eco-environment changes in the loess plateau of china. Land Degradation and Development, 24 (5), 499-510.

32. Zgłobicki W., Rodzik J., Superson J., Dotterweich M., Schmitt A. 2014. Phases of gully erosion in the Lublin Upland and Roztocze region. Annales UMCS, B, LXIX, 149-162. 